\title{
Bridging the Theorist-Practitioner Gap in IR: What are the Risks and Benefits?
}

\author{
Richard J. Cook, Zhaoying Han, \\ Maximilian Ohle and Srđan M. Jovanović
}

\begin{abstract}
The practice international relations is routinely characterized as binary, which derive from two domains, either a scientific domain, which aims to seek factual knowledge, or a political/practical domain that seeks political action. Each operates on its own praxis and eidos and forms the fundamental differentiation between the domains that has governed the working ethics of international relations professionals for the better part of 70 years. Although these norms are still in place, the specialization of IR has begun to shift this traditional practice as a growing demand for more mid-level and level-specific research, gravitating around a world with increasing uncertainties is fuelling policy research demand. The extra demand has begun to pull scholars into the field of politics and political action. How does this affect identity and our interactions? What impact does this have on bridging the theorist-practitioner gap? And where does this leave IR pedagogy? This paper shall address these questions claiming that the gap should be bridged, but with the caveat of caution.
\end{abstract}

Key Words: Theorists, Practitioners, Policy, Dichotomy

* Richard J. Cook is a Ph.D. Candidate of International Relations at the Zhou Enlai School of Government, Nankai University, China.

** Zhaoying Han (zhaoyinghan@nankai.edu.cn) is a Professor of International Relations at the Zhou Enlai School of Government, Nankai University, China.

*** Maximilian Ohle obtained his Master's Degree in International Affairs and Public Policy at the Zhou Enlai School of Government, Nankai University, China.

**** Srđan M. Jovanović is an Associate Professor of History at the Faculty of History, Nankai University, China.

We would like to extend our thanks to the three anonymous reviewers for their comments and suggestions. 


\section{INTRODUCTION}

Within the last 25 years, there has been an observable growing gap between the traditional domains of international relations research citing the theoristpractitioner dichotomies (Jackson 2017). The issue of retaining pragmatic research positions, pertaining to eidos and praxis, as opposed to the possibility of synthesis consistently raised the conundrum of "bridging the gap" or "eliminating the gap" time and time again (George 1993; Nye Jr. 2008). Not only has "bridging the gap" in international relations pedagogy been an issue for the "theorist" and the "practitioner", but other gaps have also come into contention in order to intersect various disciplines (Onuf 1989; Hollis and Smith 1990; Wendt 1991; Egeberg 1994; Thomson 1995; Hyndman 2004; Jackson 2004; Lantis 2009; Jentleson and Ratner 2011; and Kim 2017). This conundrum straightforwardly identifies a significant existing problem of blurred lines between respective professional methodologies that traditionally partitioned the two domains in research approaches (Jackson 2017). To grapple with the topos of contentions, we can recall Max Weber's differentiation between "science and politics" (Weber 1994). This envisions a distinct difference of positive research - being objective and fact-based - and normative research, being subjective and value-based. The former is highlighted as pertaining to "those that seek factual knowledge", whilst the second is acknowledged as referring to "those that seek political action" (Lepgold 1998; Nye Jr. 2008; Jackson 2017). The abovementioned being two fundamentally different appropriations is used as a foundation when approaching research. Factors of the existing gap between the two point to potential abuses or problems in how knowledge is produced and transmitted between the domains for respective purposes (Jackson 2011). Ergo, the questions that pose themselves can be summed as follows: 1) How do researchers identify themselves in the field and define their interactions between these binary domains; 2) How do they approach this gap; and 3) What are the risks to international relations pedagogy?

These questions present scholarly IR theorists and political practitioners with important considerations surrounding identity, working ethics and pedagogy, as bridging the theorist-practitioner gap becomes evermore commonplace due to growing, often instant demands for research to supplement policy manifestations. In essence, diachronic approaches to these developing forms of "trans-domainism" threaten the traditional framework of how we conduct research and aid policy practitioners. 


\section{LITERATURE REVIEW}

So far, the realignment of international relations practices has been fuelled by significant shifts taking place within international politics. The widespread notion of the diffusion of power is seen as enhancing said shifts (Strange 1996; Hurrell 2007; Lake 2017). As the Western-led international order faces mounting challenges, several scholars have begun to point towards systemic changes, entailing a power transition process, either by peaceful and harmonious means or charged with conflict (Gilpin 1981; Zakaria 2009; Kupchan 2012; Acharya 2014; and Buzan and Lawson 2015). While these dynamics are unfolding, we can already perceive how multiple notions are shaping the international systemic changes, as the increased fluctuations within the international political environment are amplifying the need for brisk policy manifestations.

These factors are producing an extensive condition of uncertainty for actors, warranting the need for meso-level and micro-level research, as opposed to broad range theory and macro research, in order to assess certain changes from a very specific standpoint (Buzan 2018). This is a challenge for academicians, as these discussions need to be orientated to aid policy output, well-informed advice and recommendations about contemporary developments for policy practitioners, in other words, to help organize a tenable division of labor within the field (Desch 2015, 386; Buzan 2018). Stephen Walt also acknowledges this unavoidable linkage between the world of science and politics, noting that "even policy makers who are contemptuous of 'theory' must rely on their own (often unstated) ideas about how the world works" in order to "make sense of the blizzard of information that bombards us daily" (Walt 1998, 29). Following Robert Cox's argument "theory is always for someone and for some purpose", some suggest that there is no gap of divide, but the embedment of "politics" into "science" (Cox 1981, 281). Nonetheless, scholars still find themselves inadvisably fixated on "grand theory", often impractical for politicians (Lepgold 1998; Lake 2011). This provides an element of dissatisfaction within the political domain with IR contributions, as most of the academic research produced can be regarded as inappropriate for policy practitioners who are more inclined for clear-cut measures and digests (Morgenthau 1958, 390; Tanter and Ullman 1972, 250; Herrmann, Kratochwil, Lapid, Moravcsik, Neumann, Smith, Harvey, and Cobb 2003; and Lake 2011). As Lepgold states, "they [policy practitioners] want to know that if condition Z exists or that if they do X, Y is likely" (Lepgold $1998,45)$. Jentleson similarly identifies the "need to bring policy relevance back in to the discipline, to seek greater praxis between theory and practice" (Jentleson 2002, 170). We, therefore, see a low regard for theory, which is almost unusable 
for policy practitioners, and is consequently often shunned (Walt 2005, 24). In that light, the core challenge concerns how to increase the quality of research to supplement policy manifestations appropriately (Lepgold and Nincic 2002, 2-5; Nye Jr. 2008, 597).

The result of these demands has constituted the need for a remedy, which envisions significant specializations within the traditional binary methodologies of IR research - Science and Politics - as suggested by Patrick Thaddeus Jackson (2017). He refers to these pursuits as relating to "public policy analysis" and "academic social science", in a similar manner to that of Lawrence M. Mead (1985). The disparity between the two allowed Jackson to rationalize that IR praxis can be divided into the "pursuit of factual knowledge" and the "pursuit of action", providing much more clarity to the specializations of IR practices. Ergo, according to Jackson's work, IR can be divided into science with the pursuit of factual knowledge and politics with the pursuit of action. Additionally, the tab of science is further divided into its practitioners, scholars and experts, as politics is divided into policy intellectuals and policy practitioners (Jackson 2017). This functions as a connective to Joseph Lepgold's work, which formulated IR activities as divided into two primary domains of "Theory building" and "Policy applications", each sub-divided into groups with specific focuses and goals identified. "Theory building" is subdivided into Group 1 - "general theory" and Group 2 - "issue orientated puzzles", whereas "policy applications" is likewise sub-divided into Group 3 - "case-orientated expectations" and Group 4 -"policy making" (Lepgold 1998, 47-50). ${ }^{1}$ In addition, Lepgold points out that a range exists from Group 1 to Group 4, from low to high proximity of specific policy problems, "General theory" being the lowest and "policy making" being the highest.

Despite this distinct categorization of academic identities, the notion of IR members crossing these domains to fulfill certain needs and demands is omnipresent, specifically concerning research methodologies that assist and expand the existing paradigms of IR epistemology. Numerous scholars, such as David A. Lake, have expressed the need for more mid-level or puzzle-focused research to aid policy development, emphasizing the intertwined character of the two domains (Lake 2011). This constellation, however, raises the question as to whether "bridging the gap" remains frictionless, while still maintaining

1 Here Lepgold identifies a useful pattern of dichotomy regarding IR practices and goals, with each group having a specific responsibility serving the greater IR field. Group 1 serves the need for explaining a broad range of empirical phenomena; Group 2 analyses specific cases that are restricted to a providing an explanation; Group 3 seeks to explain matters directly related to policy-relevant events or situations; and Group 4 focuses on specific policy options. 
the responsibilities of seeking factual knowledge and seeking political action. Though most conclude that the gap needs to be bridged as opposed to being eliminated, we run the risk of blurring the lines between responsibility distortion and loss of specialization focus, arguably even an uncoupling of the scientific method from the scholar for a political one (Nye Jr. 2008, 593). The reasoning behind the elimination of the gap leans towards a Popperian norm of replacing the old method with the new, in the wake of developing demands in the field (Popper 2002, 19-20, 57-73). ${ }^{2}$ This leans to an uneasy integration of "science" as a focus on fact and "politics" as a focus on action, that can distort the lines between these respective academic arenas (Jackson 2017). The result is tension between these respective practices or sectarianism, which in turn raises questions about professional output (Lake 2011; Lake 2013). Each academic domain or "sect" that we organize ourselves into has significant effects on our output, thus directly influencing theory and epistemology.

We are confronted with two Weltanschauungen here. The first acknowledges the bridging of the gap as a necessary friction in the contemporary age and is seemingly having scant difficulties in crossing the dividing lines between "science" and "politics" (Nye Jr. 2008). The other encompasses those who remind us of the dangers, specifically the hazard of the loss of focus on responsibility, as well as a merger between the two arenas into a "proto sciencepolitics field" (McNamara 2009). The increased exposure of IR practitioners to differing domains and sub-domains with dissimilar goals inevitably leads to the issue of dichotomy in the field, as well as a more pressing matter: how do we identify ourselves within the field? This crucial conundrum raises ageold concerns about the appropriation of responsibility as well as compound questions on how to bridge the gap between differing IR domains (Bliss 1929; Foucault 1970; George 1993; and Nye Jr. 2008). The practice of maintaining a dichotomy within an academic field pragmatic should provide a useful framework for how we identify ourselves, understand interactions and develop the field alongside the rigors demands from current affairs.

Members of the IR community may engage in multiple domains and thus identify themselves as "bridging the gap". Referring to Jackson who laments in doing so, it is here where we identify a significant cause for concern on the part of blurred lines (2017, 702-703). Crossing the divide requires IR practitioners to

2 Here we refer to Karl Popper's paradigm of falsification, by way that if there has been a development of sort, the previous praxis shall be replaced by a new praxis through logical deducing; thus it has been argued that traditional norms of "science" and "politics" are merging, meaning the "gap" is being eliminated. 
transfer themselves to a dissimilar set of exclusive responsibilities. It is at this particular point that the notion of prudence steps in. Failure to do so magnifies a potential new identity, one that may conjure up a set of warped, entangled responsibilities, the so-called policy thinker. However, not all academicians frown on this notion. In his much acclaimed Bridging the Gap: Theory and Practice in Foreign Policy, Alexander L. George voiced his aggravation at the ineptitude of many IR scholars and experts for seeking too much theory and their lack of true insight into the political machine by way of experience (George 1993). He supports this hypothesis by stating that those who are closer to government "recognize that generic problems exist in the conduct of foreign policy" (George 1993, xix). Those with practical experience may be better equipped to know what they are dealing with, in terms of domainhopping, embodying the factors attributed to pluralistic science. To further aid the prospect of a new identity within the domain, there have also been calls to grapple with a wider range of activities and groups that fall between said domain boundaries (Lepgold 1998). From a pragmatic perspective, should a custom be practiced universally, it may as well become law.

An implication can be made that a type of "trans-domainism" could exist, teetering between the separate domains of science and politics that could have an exclusivity to operate between these two domains independently, due to their increasing exposure, as there is a need to further supplement the notion of exchange. As Lepgold concludes in his work, he signals that there is more than meets the eye: "There is a wider range of IR groups, at least in the United States, than the theorist-practitioner dichotomy implies, and the infrastructure that supports their activities has created a framework for useful exchanges. More such interactions take place already than is commonly acknowledged" (Lepgold 1998, 60). From Lepgold's perspective, trans-domainism might already be in existence, yet unacknowledged. His thoughts directly depict the state of IR within the United States; it can be argued that trans-domainism exists even beyond the USA, particularly within those scholarly communities that have achieved full maturity within the field of IR.

\section{THE DIVISION OF LABOR - THE DYAD BETWEEN SCIENCE AND POLITICS}

International relations have long been divided into a series of schools, which most scholars would align themselves, depending on their respective research tradition. These paradigms are most often identified as realism, liberalism, 
Marxism and constructivism (Sil and Katzenstein 2010). We are then told about the formative nature of these schools, and are then introduced to the long list of sub-schools, neo-, offensive-, defensive- and the "isms" as well as the "non-isms", such as the English school, as a single example. Here, Barry Buzan specifies that International Relations, as a discipline, is characterized as an importing mechanism, by which a potentially diverse array of scholars, depending on their prime discipline (such as psychology, economics or sociology), "'sell' their ideas into the IR community" (Buzan 2018, 401).

These respective research traditions b(l)ind us, whether we like it or not, into using a set of core assumptions when conducting research. The importance of using these parameters ensures an established epistemology for our respective research. They ensure that we, as academicians, are knowledgeable about our different units of analysis, understand our standpoint, and the direction in which we are going. Considering the selective nature of humanity, subscribing to a research tradition ultimately points to a conflicting basis of standpoints; however, this might lean towards a cooperative nature of research, as respective research can be cross-compared, progressing the IR field as a whole. In retrospect, this division of labor or these epistemological aspects of IR define our boundaries, bringing order to what otherwise would be disarray.

In contrast to this, we are not immediately told about another traditional division of labor within IR or the "Two Worlds of International Relations", related to a more substantial pathology that defines us as members of the "science" or "politics" domains in IR (Hill and Beshoff 1994; Nye Jr. 2008, 593-594). In fact, this issue has only slowly crept into the greater IR debate, as "academics became more methodologically and epistemologically self-conscious" (Lepgold 1998, 45). When engaging in international relations as individual beings, we engage in domain selection, marshaling ourselves into the science and scholars domains. It is here where there is a requirement for academic focus. As the traditional research methodology schools of IR are divided, the science or politics domains of IR are all too separated by praxis, as shown in figure 1 (Nincic and Lepgold 2000, 129; Jackson 2017). Here we see each camp further divided into two other domains. The arena of science can be envisioned with two subsects, scholars and experts. Likewise the arena of politics can be envisioned with two sub-sects, policy intellectuals and policy practitioners: 
Figure 1. International Relations Section Division (Jackson 2017, 700-701)

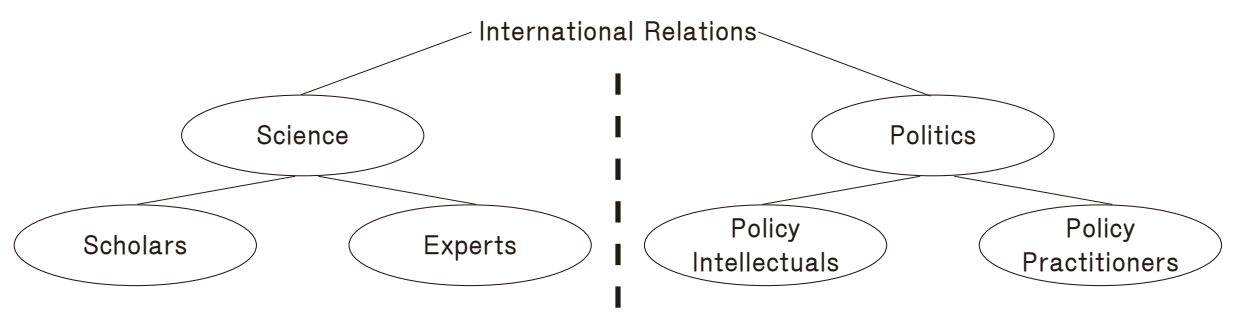

Each particular domain exerts a particular goal, although all are bound to the notion that they collectively dwell within the realm of International Relations in a holistic or top-down mode in order to explain and understand particular role (Hollis and Smith 1990). These particular goals are first allocated into the science and politics domains, pertaining to our understanding of modes of inquiry (Wendt 1991, 384). The first "claims to enhance our factual grasp of things", whilst the later "claims to get things done" (Jackson 2010; Jackson 2017). These similarities regurgitate themselves within their respective domains once more, culminating in a symmetrical partition of each (Abbot 2001). This marks the detachment within the IR academic methodology intention, whilst also delivering us to a specific methodological view (Jackson 2017, 700). Thus, using Weber's logic and differentiation norms, we can see in Fig. 1 that the classifications of "scholars", "experts", "policy intellectuals" and "policy practitioners" assist in the norms of identification for those engaged in IR.

\section{CONTEXTUALIZING THE SUB-DOMAINS: THE CLASSIFICATION OF PROFESSIONS AND THEORETICAL OUTPUT DEMANDS}

Within IR, "Scholars" are focused on five activities: puzzling, conceptualizing, describing, and making casual inferences as well as pedagogy in a quest for broadening their research output (Keohane 2018, 251). This sub-domain predominantly consists of IR teachers, lecturers and professors based in IR departments as members of educational institutions. Here they can perform research on their own accord, arguably independent and self-focused. "Experts" are presented as those who are given puzzles for the sake of providing advice on problems. This sub-domain involves, for instance, think-tank researchers and program coordinators. These experts, therefore, receive topical foci and are contracted or refined towards a specific task. "Policy intellectuals" encompass a role more directed towards political action. They are tasked with providing high-end policy advice and are constrained to serving a political 
interest, as opposed to serving the pursuit of scientific fact. "Policy practitioners", on the other hand, embody those who are direct members of a governmental branch. Examples of this position are Members of Parliament, Members of Congress or Senate etc. They are charged with running the state and seek the best form of political action to serve what they believe is in the best interests of the state and their own self-interest (Wilson 1981; Trow 1984; Rathburn 2012; and Jackson, 2017).

Considering these "Weberian" traditional multi-domain methodological divisions in International Relations, we can observe that the intra-epistemic nature of knowledge to pass between domains points to a division of labor within abovementioned research modes. In this knowledge-driven model, based upon the impact of research, we see certain appropriations. As Walt wrote, "general theory establishes the key concepts, methods, and principles that guide the analysis of specific empirical puzzles (such as alliance behavior, institutional effects, crisis behavior, and ethnic conflict), and these results are then used by policy analysts examining specific cases or problems" (Walt 2005, 40). ${ }^{3}$ This insinuates that despite the notion of the division of labor, there are further overreaching practical concerns for identity.

These groups are linked in various manners; traditional norms of this dichotomy readily outline not only the specific functions of each, but also the specific relationships they have with each varying sub-domain. These relationships form the foundation of the IR knowledge system and provide it with purpose. Should we borrow Lepgold's understanding of said knowledge system, we could see a range of research puzzles, responsibilities and orientated knowledge transgressing the spectrums with specific foci (Lepgold 1998, 50). ${ }^{4}$ In a manner of speaking, Lepgold is expressing the supplementation process that groups or sub-domains practice with each other. He recognizes that Group I provides research knowledge that can be used to "speak directly to policy issues, or be used to reframe Group II puzzles in ways that reflect connections among various IR puzzles", whilst "Group II puzzles, in turn might allow those in Group III to see more easily which Group II research questions and bodies of work apply to specific sets of policy problems" (Lepgold 1998, 50). Resubmitting Jackson's take on the issue, we see scholars providing a range of research knowledge applicable for use up and down the spectrum of sub-domains, as too with that of experts. However, these goals and responsibilities maintain

3 This aspect of knowledge "trickling down" through the differing domains where appropriate is also noted by Weiss (1978).

4 Lepgold acutely acknowledges the manner in which knowledge is produced and passes from one Group to another, with a specific intent. 
variance, as to avoid a potential calamity of multiple praxes.

Building upon the abovementioned, it would be fair to assume, in our contemporary world, that not only respective sub-domains have integral relations to other respective sub-domains, but respective researcher classifications have more appropriate value within other sub-domains as well. For instance, broad theory, mid- and theory-specific research and puzzles, each represent a different typology of appropriated knowledge and provide different supplementary means for each sub-domain's demands (Lake 2011; Lake 2013; Keohane 2018, 251). Each sub-domain has different relationship demands to this knowledge, depending on whether the knowledge is organized as 1) broad theory/puzzle; 2) mid-level theory/puzzle; and 3) specific theory/puzzle. From the perspective of such a classification, we can apply a top-up understanding of the dichotomy, as outlined by Lepgold and Jackson, thus enhancing our understanding of how IR members "bridge the gap", along with their intentions and how the IR knowledge system works (Anscombe 1963, 2-5)..$^{5}$

\section{THE RELATIONSHIP OF SCHOLARS WITH THE SUB-DOMAINS}

As there is a difference in research incentives being accentuated by the demand from policy practitioners, further gradation may well be appropriate, specifically if dialogue is to be enhanced (Shipan and Volden 2012; Spiel and Strohmeier 2012). As stated, factors of theory/puzzles are in direct contention to bridging the gap, as well as those IR members who make certain transitions (Lake 2011; Lake 2013). Understanding these bridging factors can also re-focus the lens to allow a more detailed explanation for how domain interactions take place. Therefore, we can envisage IR knowledge relationships with the three applied theory/puzzle levels: broad level theory/puzzles, mid level theory/puzzles, and specific level theory/puzzles.

Outlined in Figure 2, we can see the applied three theory/puzzle levels, as well as the factors of scholars' knowledge relationship between the sub-domains. Starting with broad level theory/knowledge, we can see that this knowledge provides uses to experts, however becoming less desirable as we move into the politics domain. For policy intellectuals, sifting through volumes and tomes of selected books and journals can be described as inappropriate or impractical due to time constraints; their focus is compiled in reports and memos instead (Nye Jr. 2008, 598). As to policy practitioners, they, at the seat of the government,

5 Here Anscombe explains various factors of intentions via insinuations yet, varying outcomes may differ from what was originally intended. Here, these intention norms can be applied to factors of various IR members engaging in different domains, yet intending to maintain their original domain intentions. 
require to be able to filter through documents in good time in order to be efficient (Shipan and Volden 2012). They require time-sensitive advice. Where broad theory/puzzle lacks in capacity, mid-level theory/puzzle makes up for it, as it is more orientated towards focused definitive concerns within a trimmed boundary. However, policy practitioners have little time to seek potential policyaiding knowledge via sifting through these papers as well (Shipan and Volden 2012). For them, specific level theory/advice is directly applicable to their demands, while they can still complement demands of other sub-domains.

Figure 2. International Relations with applied three theory/puzzle levels - Scholars

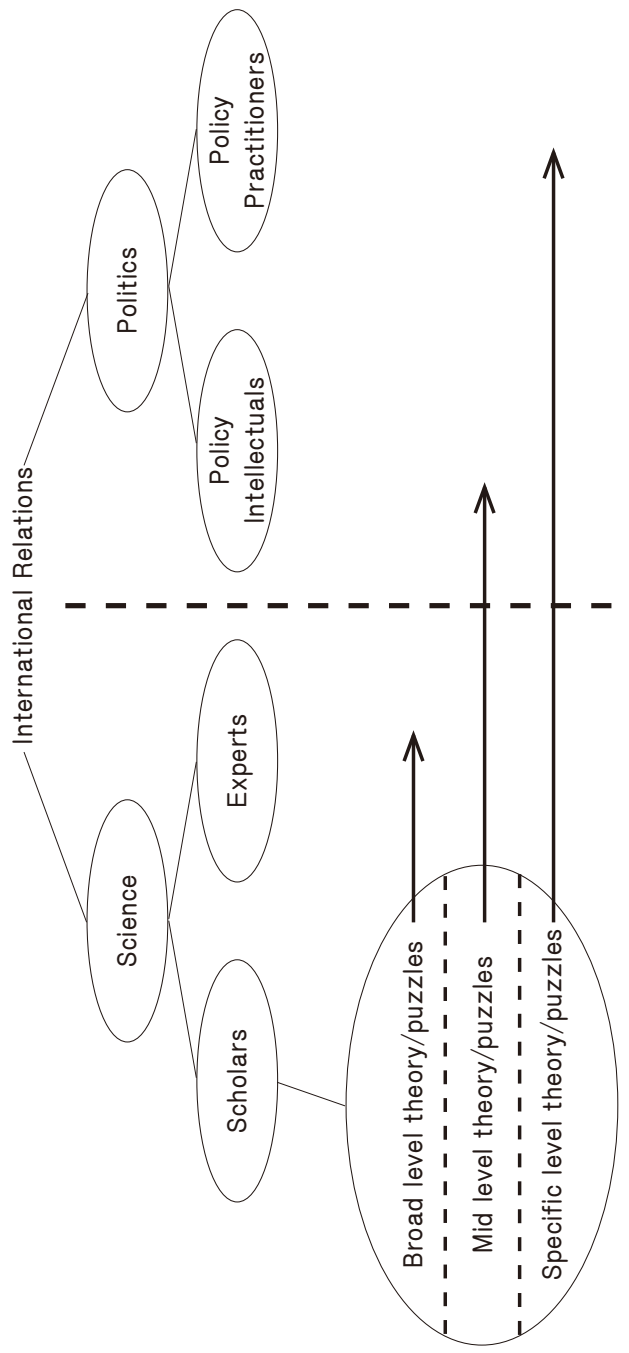




\section{THE RELATIONSHIP OF EXPERTS WITH THE SUB-DOMAINS}

Applying the three theory/puzzle levels to the experts sub-domain, we can identify a different partition of knowledge to the differing sub-domains. As scholars independently pursue factual knowledge free from instruction, they can use all aspects of the "theory/puzzle" produced from the experts sub-domain. Similarly, broad level theory/puzzle knowledge is not appropriate for politics domain practices. In addition, as experts usually seek or are given a theory/ puzzle for the sake of providing advice on problems, they are less associated with broad level theory/puzzle activity. However, the vast base of scholarly production supplements their activities. The mid level theory/puzzle knowledge they produce, in the name of providing advice on problems, forms a factual basis that is useful to policy intellectuals, whilst their specific level theory/puzzle knowledge produced provides usefulness to policy practitioners. 
Figure 3. International Relations with applied three theory/puzzle levels - Experts

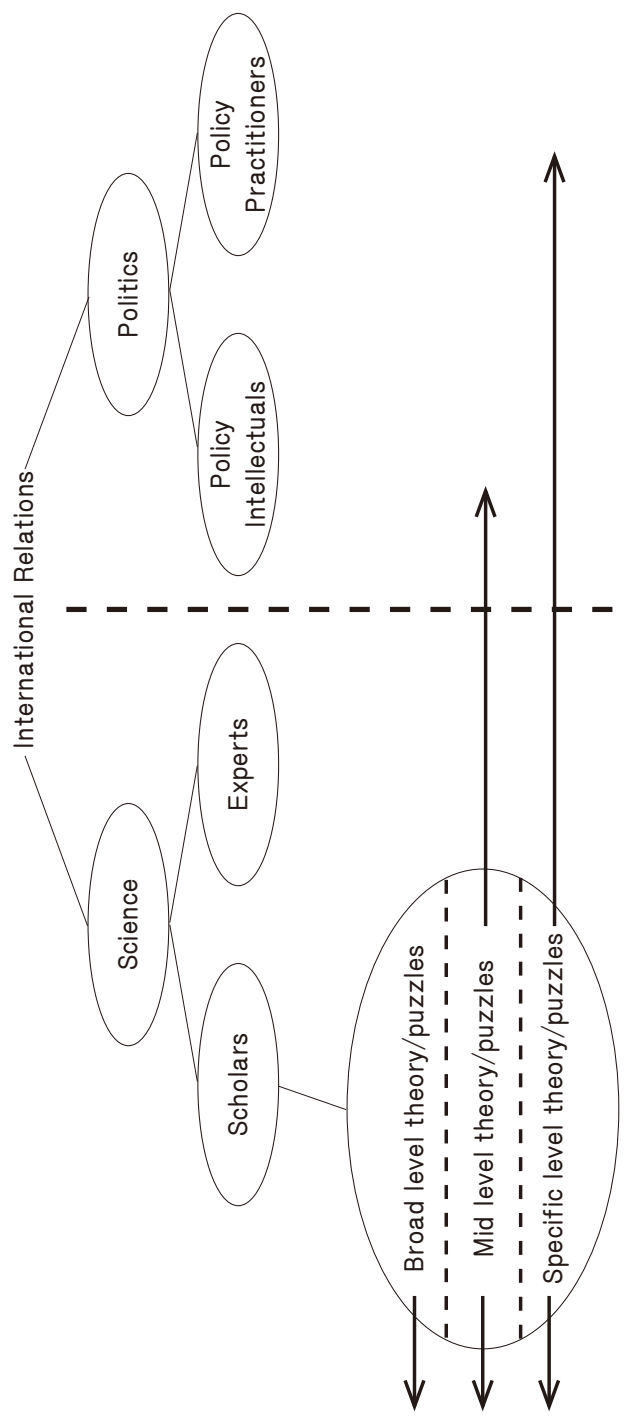

THE RELATIONSHIP OF THE POLITICS DOMAIN WITH THE SCIENCE SUB-DOMAINS

Switching our perspective to the politics domain, we see a reverse pattern emerging, fuelling specific demands for appropriate knowledge. This demand is influenced in two ways. Firstly, demand within IR is driven by international 
events. An actor that has vast engagements on the international stage will require a significant and sophisticated IR knowledge system that provides adequate knowledge within its politics domain, whilst needing to have a highly developed science domain in order to provide a rich basis for the academia, which will in turn produce a range of knowledge to supplement the politics domain. These aspects increase the actor's capacity to be active on the international stage.

Secondly, demand is directed to rational, time sensitive contemporary research and knowledge. Nevertheless, as previously stated, this need for mid-level and specific theory/puzzle is supplemented by scholars' research, including a need for some broad theory/puzzle to form a foundation for other forms of study. This points to a need for balance between each specialization. Enough broad theory/ puzzle might supplement both mid-level and specific theory/puzzle, whilst a range of mid-level and specific theory/puzzle meets the demands of politics.

\section{IMPLICATIONS FOR THE DIVISION OF LABOR}

It is these understandings of the IR dichotomies that provide a practical and rational identity, while each domain and sub-domain provides a specific focus for the rest. The demands provide the basis for differing research knowledge to be passed between one another, whilst each domain maintains a primary function. This represents the processes of research, organization, distribution, legitimization, and use in an IR knowledge system. This behavior proposes that individuals, both alone or in groups, act in patterned ways (Ginsburg and Gorostiaga 2001). The task of the individual is further determined by those patterned actions, conforming to a rationale that seeks fact or action, and to what degree in specifics can their research or actions supplement their chosen field (Mingst and Arreguin-Toft 2011, 9). Despite the fact that the criteria of demands change, as they are not static, they are in fact linked to the developments of actors' status, engagements and conduct on the international stage; scientific parameters remain locked. ${ }^{6}$ For states increasing their involvement or becoming more involved in international affairs, demand must be met. When knowledge cannot supplement developments or when new affiliations for IR members become available, not only does research knowledge bridge the gap, but also IR practitioners themselves. This leads us to look at how demand and affiliation of IR practitioners impact these blurred lines.

6 Scientific parameters are not necessarily locked. This is said in the context that in order to carry out "good science", variables and methodology must conform to some consistency. 
The transition of a scholar or expert to a policy intellectual or policy practitioner is tied to an "in or out" tradition, depending on the organization or government they serve; in many respects this "transition tends to become a one way street" (Nye Jr. 2008, 594). This "in or out" tradition is based on the scholar's or expert's re-adaption of personal beliefs to certain political actors that are seeking policy advice from the science domain, thus leading to the selection of suitable scholars and experts conforming to the latter's political profile. Not many top ranked scholars are currently going into government, and even fewer return to contribute to academic theory (Nye Jr. 2008, 594). The separate domains contain different cultures, norms of interaction and discourse (Lepgold and Nincic 2002, 136). In a sense, most IR science domain members never indulge in the politics domain further than the policy intellectual sub-domain. Only a very few select names have actually moved directly into the policy practitioners sub-domain; "of the 25 most influential scholars listed by Foreign Policy, only four have held top-level policy positions, two in the U.S. government and two in the United Nations" (Peterson, Tierney, and Maliniak 2005, 62). Yet, bearing this in mind, there have been notable but rare contributions from scholars who have transgressed the gap. Notables include Arnold Wolfers, Carl Friedrich, McGeorge Bundy, and Thomas Schelling (Nye Jr. 2008, 596).

As noted by Nye, bridging the gap is as much about appropriateness and relevance, meaning that certain IR members are well schooled in science and politics and their responsibilities, as much as their shifts to other domains are related to the demand of a certain issue - solving a particular puzzle, or briefing government aides (Nye Jr. 2008). However, from such experiences, an IR practitioner who has intensely shuffled back and forth from domains for certain projects or roles can be said to possess an important perspective. As the "in or out" aspect goes, these IR members can ultimately equip apprentice academics for the future and help carve out their portfolios for different roles in the academic spectrum (Nye Jr. 2008, 595). Such educators provide a mix of both domains.

From the previously structured groupings we can envision certain individual academicians belonging to a specific domain. An academician is nonetheless not exclusively a member of one domain, nor do they have to be; they are able and often do bridge from one domain to another in order to perform specific tasks. Whether these tasks are coined with "claims to enhance our factual grasp of things" or "claims to get things done" should be taken seriously and not muddled with (Jackson 2017). For a specific task, the academician must readily appropriate the right epistemological domain in order to maintain correct conduct and focus; this is a skill that many are not able to perform or 
feel comfortable performing. Being associated with a specific domain ultimately means more or less compatibility with one another. Thus, academic prudence is of paramount significance, which leads us to the next aspect of the debate, which is the "puzzle".

Encompassing the academic nature of studying International Relations and taking forth the domains of academic association previously highlighted, we must now reaffirm the importance of keeping focus on the puzzle. As we teach in IR 101, we task young practitioners with associating knowledge to find, develop and answer puzzle-focused research. Why does IR hold tightly to this formula? To put it bluntly, in the words of Zinnes, "puzzles are in fact questions, however not every question is a puzzle" (Hopmann, Zinnes, and Singer 1980, 316).

Consolidating on the norm of IR puzzles we again must deem it necessary to provide structural association with puzzles; in short, each domain, be it scholars, experts, policy intellectuals and policy practitioners are ultimately focused on their respective particular puzzles. All these puzzles are International Relations puzzles; however, they are divided by their goals, attaining to enhance our factual grasp of the political universe, or to "get things done". These respective puzzles require independence from one another in order to maintain clarity and focus. Nonetheless, research from one domain may transcend domains in order to build on other research or impact other goals. For instance, a scholar will conduct research on a relevant topic with the goal of seeking to enhance factual knowledge. This research can be then picked up and read by a policy intellectual and re-orientated into knowledge of politics for application to government policy by policy practitioners. This was not the original goal of the research; it, nevertheless, transcended the domains, yet the research was conducted, and then re-orientated toward respective domains.

Whilst IR members associated with seeking factual knowledge and seeking political action are oriented towards either the science or politics domains, those science members that engage in supplementing the demands for mid-level or specific level theory/puzzle walk a fine line in accordance to their traditional responsibilities. However, it is not just the demand that pulls them and their work towards the gap. The factor of affiliation is also of concern.

With actors that have a larger demand for policy driven advice, supplementation will not elevate IR members from hopping over the gap. It may in turn stem the flow and cleanse the blurred lines between dichotomous responsibilities, though the gravitational pull to be involved in the pursuit of political action can be said to be "attractive". Being thrust into the political arena, particularly the policy practitioners domain, further fuels a dream of becoming the next Cardinal-Duke De Richelieu, Henry Kissinger, or Robert 
McNamara, however unlikely it may be. Yet, not so long ago, it was through the demands of the Cold War when we saw a range of scholars being enlisted into policy advisory roles to fill the upsurge in the demand. Jentleson points out that "whereas thirty or forty years ago academics were the main if not the sole cohort of experts on international affairs outside of government and international institutions, today's world is a more competitive market place of ideas and expertise" (Jentleson 2002, 181). Therefore, it is not unusual to see questions about strains on academic responsibilities in times of increased demand. In fact, it may well be the criteria for identifying constitutional moments of increased global pressures are seen as relevant for an actor.

Affiliation factors may well be even more consequential for the fledgling IR researchers. As they enter a realm of intense demand and competition among their peers, the quick fix of seeking a "grand theory" for imminent fame is proving somewhat challenging (Behnke 2001; Linklater 2009; Brown 2013; and Eriksson, 2014). This increasingly detrimental propagation throughout IR pedagogy is practiced in the false assumption that by winning this "lottery", they could assume a place within the government (Brown 2013). The thought of "selling" this "grand theory" onto the political arena, particularly to the policy practitioners, further fuels a dream of becoming the next great statesperson (Lake 2013). As is widely accepted within IR, the grand prize of the lottery is discovering the "holy grail", i.e. conceptualizing the universal grand theory. However, the likelihood of achieving such theoretical output is, even for the most famous scholars, improbable. Overcoming this is more or less a matter of personal maturity.

The unruly fact of the matter is that these blurred lines are a product of demand, affiliations and maturity. Our selective nature to identify with one mutually exclusive arena in the "science" and "politics" spectrum, as well as our ability to navigate these struggles, are fundamental to academic conduct when engaging in research.

\section{THE IMPACT ON IR PEDAGOGY}

Concerning IR pedagogy, bridging the gap or crossing the divide presents us with an abstruse dilemma derived from social structure and thought. More specifically, the dilemma is rooted in how IR knowledge is circulated by IR knowledge repertoires. Although not rooted in the specifics of IR knowledge exclusively, Riley Philip's research on language, culture and identity contains significant insights that allow further debate pertaining to the risks of bridging 
the gap between the "science" and "politics" domains and the potential risks this has for IR pedagogy (Philip 2007).

For the future of IR pedagogy and the identified dilemma of crossing the proposed bridge, there stands a further three epistemological avenues, that can operate the IR pedagogy as: 1) "an epistemological rupture" (Bachelard 1938); 2) "epistemological anarchy" (Feyerabend 1978); or 3) "an axiomatic developing epistemology" (Lakatos 1976). Ergo, factors of knowledge between a "master" and an "apprentice" as well as the transposition of those identities with their respective domains play a critical role on the pedagogy of IR.

If IR is taken as an intrinsic knowledge system, scope can be centered upon its structure and function with relation to the outlined domains. As such, via the lens of Riley Philip's research, knowledge is transcribed and structured as such:

Figure 4. The IR Social Knowledge System (Riley 2007, 30)

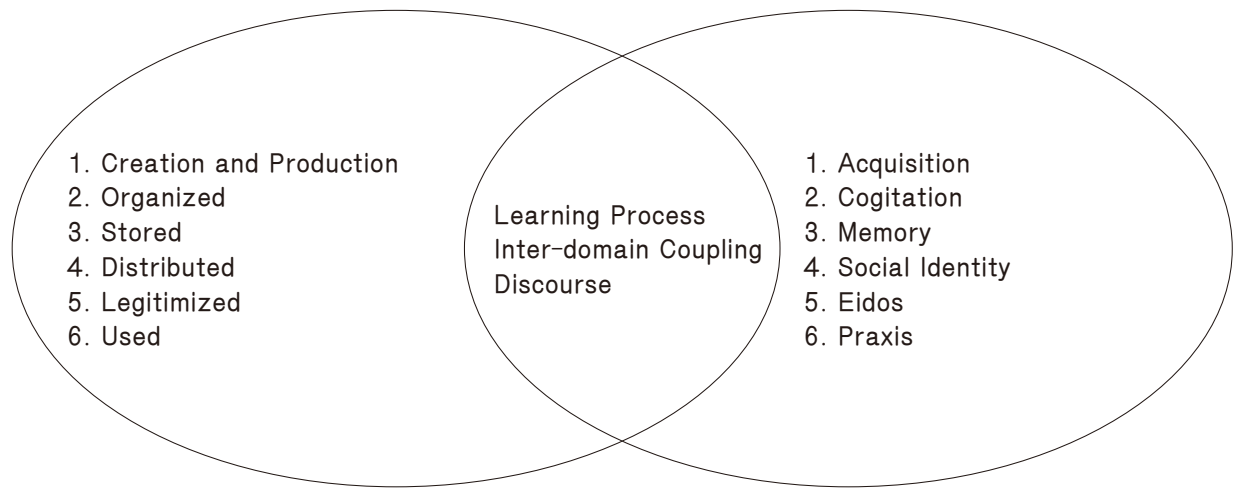

Regarding the aforementioned "creation and production", IR is producing knowledge both through a scientific lens with the use of theory, searching for questions, puzzles, and answers, and via "practice", which offers empirical value to any particular study. This knowledge is divided into "domains" and "subdomains" which embody the "organized" aspect. Thereon, it is stored within appropriate institutions (universities, think tanks etc.) and distributed for use by members of epistemic communities for the purpose of the creation and production of knowledge. Legitimacy of this knowledge is then established via its use within epistemic communities and their interests. The use by epistemic communities energizes discourses, research programs and debates within the IR field, as individuals of the field focus upon specific dilemmas. This pattern is considered the standard norm of the IR research custom and is an established doxa within the field. 
The bridging of the gap entails fundamentally differing customs and doxai due to the "science" and "politics" goals. The social learning process within the acquisition of knowledge through inter-subjective couplings and overall discourse is rooted in different designs and objectives. For the individual who crosses the bridge, the acquisition of knowledge and its practices is extended into the opposing domain. This in turn influences specific cognitive categories, thus the very use of knowledge and the criteria of the opposing domain may be seen as compromising the subject. Memories of the researcher's original domain and its practices will also become compromised, as the established customs and doxa break down. In such an instance, the individual's social identity, their role due to the opposing domains' interests and requirements, is altered, therefore shifting their eidos or Weltanschauung - sets of ideas, beliefs and values - regarding their use of IR knowledge and purpose. As such, the praxis of the individual becomes augmented, compromising respective domains and their practices with the use of IR knowledge.

Knowledge circulation as 1) structure, 2) outlook, and 3) use undertakes fundamentally different approaches, designs and aims for different goals. An individual who crosses the bridge into the opposing domain establishes knowledge repertories based upon knowledge circulation through the IR social knowledge system, which as stated, can critically expose the individual to a differing eidos and praxis that can have significant repercussions on IR pedagogy. In this sense, an individual (master) who has crossed the bridge and who then engages in pedagogy practices may educate a student (apprentice) with a comprised eidos leading to a significant risk. This circumstance of corrupted eidos may be transferred to the apprentice leading to a clouded understanding of praxis i.e. a student who is then using the incorrect set of research customs to engage in IR knowledge creation and production.

The contemporary IR discourse has brought about numerous scientists and practitioners, crossing the bridge between the domains and, thus, functioning as examples how a particular eidos is imprinted in the next generation of students and manifested in the epistemic communities. They can be divided into various groups for further contextualization: (1) scientists becoming political practitioners and potentially returning to academia; (2) political practitioners becoming scientists and subsequently once again turning to their original praxis; and (3) scientists who are simultaneously political practitioners. In the following sections, these groups are exemplified by referring to several individuals who have crossed the bridge between science and practice.

(1) Among the scholars having become political practitioners, Henry A. Kissinger is one of the most recognizable examples. During his scientific career at 
Harvard University, he developed his concept of realpolitik, the raison d'être of which was based on the protection of American ideals in recognition of his own personal experiences and reflections as a Jewish immigrant from Nazi Germany (Suri 2008, 746). This formed the basis for the deeds as a political practitioner, in particular as National Security Advisor (1968-1973) and Secretary of State (1973-1977) under President Richard Nixon and President Gerald Ford, thus contributing to the ascendance of neoconservative idealism in American politics (Grandin 2015). After his return to academia, he further dedicated his work to the contextualization of American exceptionalism, revealed in his teaching activities at Georgetown University and remarkably covered in his late works Diplomacy, On China and World Order (Kissinger 1994; Kissinger 2011; Kissinger 2014; Codevilla 2015).

(2) After their political career, various practitioners turn to academia to pass on their experiences embedded in an analytical framework related to scholarly IR work. Sigmar Gabriel is one of the most recent examples to be involved in teaching activities following his withdrawal from political decision-making in Germany. Prior to this, he served as Minister-President of Lower Saxony (1999-2003), Minister of the Environment, Nature Conservation and Nuclear Safety (2005-2009), Minister of Economic Affairs and Energy (2013-2017) and Minister of Foreign Affairs (20172018). Running parallel, he led the Social Democratic Party of Germany (SPD) from 2009 until 2017 (Deutscher Bundestag 2018). Subsequently, Gabriel was recognized as a guest lecturer at the University of Bonn and Harvard University, giving courses in foreign policy analysis. Yet, he also used this opportunity to disseminate his own personal point of views during the seminars, as he has been guiding his students to develop perspectives how the EU could formulate a coherent policy on, inter alia, the civil war in Syria, the engagement with the USA, Russia and China, as well as the relations with Turkey. Although he claims that he also wants to learn from the students' perspectives, his guidance essentially conforms to SPD tenets and German national interests - an influence stemming from his political eidos, which he manifested during his activities as political practitioner (Himmelrath 2018; Ismar 2018).

(3) Committed to both academia and political praxis, Michael Stürmer has been recognized as one of the most prominent scientists from Germany who had been teaching history at the University of Nuremberg-Erlangen (1973-2003). $\mathrm{He}$ is widely known for his right-wing conservative views on how to remember history during the Historikerstreit (historians' dispute), denouncing the leftwing political forces, primarily the SPD, and raising concerns about the loss of memory and pride as a destabilizing factor for Germany's responsibility in world politics, particularly referring to its alliance commitments (Stürmer 
1987). Simultaneously, Stürmer was serving as an advisor (1980-1986) under Chancellor Kohl, whose policies deeply imprinted a conservative character based on the former's historical and political interpretations conforming to the esoteric discourse of traditionalist elite groups. These perspectives were also reflected during his lectures at the University of Nuremberg-Erlangen, thus revealing a complex interplay of eidos between his academic work and political praxis under Chancellor Kohl (Krüger 2013).

Joseph S. Nye, Jr. is also committed to academia, whilst being involved in political praxis. Since he obtained his Ph.D. at Harvard University in 1964, Nye has been involved in teaching and research undertakings, the latter of which inter alia refers to the complex interdependence theory, which he developed with Robert O. Keohane, and the concept of soft power (Keohane and Nye Jr. 1977; Nye Jr. 1990; Nye Jr. 2004). Simultaneously, his academic commitments are supplemented by his advisory activities, which are aiding the aforesaid theoretical conceptions and pedagogical abilities. As in the case of Nye, the interplay between science and politics is revealed, thus contributing to the manifestation of his personal eidos in both domains.

How, then, do we help bridge the gap? Riley's drawing upon the Innate Intersubjectivity Theory might be of interest (Markova 2003; Braten 2006; Riley 2007,33 ). By establishing intersubjectivity - a state of shared meaning within a dyadic interaction such as any pedagogical activity - entering a "social and meaningful contact with another" will enable an "innate capacity to recognize others as human beings" (Riley 2007, 33). Consequently, understanding the seemingly "opposing" domains within a master-apprentice relationship should become less problematic. Trevarthen defines intersubjectivity as "the sharing of experiential content (e.g. feelings, perceptions, thoughts, and linguistic meanings) among a plurality of subjects" (Trevarthen 2008, 1). Said subject plurality, in our case, is slimmed down to the master-apprentice dyad, within which intersubjectivity can be reached via sharing of abovementioned personal experiential instances, such as personal views/perceptions, thoughts and ideas, and even emotion.

From a scientific perspective, it might be of use to stress, the sharing of intellectual patterns (thoughts, ideas, etc.) is of no special interest, as it goes without saying. The sharing of emotions, however, might be too much for some practitioners, which is why we need to further stress it. The fear of bridging the divide (an emotion in and of itself), coupled with the potential mistrust of the opposing side, might play a crucial role in the lack of success within an attempt to bridge the gap. The subject might be fearful, skeptical, distrustful, or perhaps outright disgusted towards it. Thus, the establishment of an intersubjective 
dyadic relationship with special emphasis on the emotional might be the key point. This, however, opens up a plethora of connected research venues, none of which can be discussed within the frame of this article, as the establishing of intersubjectivity alone warrants significant research on its own. A problem poses itself though, according to the Intersubjectivity Theory, intersubjectivity is innate, and comes naturally to infants, and can be "lost" with age (Nagy 2008; Trevarthen 2008, viii; Delafield-Butt and Trevarthen 2013). Nevertheless, it can be restored within adults. In other words, with patience and a positive view towards intersubjectivity, Phillip's "inter-domain coupling" can arguably be achieved with less distress.

\section{CONCLUSION}

Looking back at the development of IR as a practice, there have been at least two constitutional moments that have contributed to the way we engage it within the academia. The first is E. H. Carr's "critique of the interwar liberal internationalism as 'utopianism' and his call to bring a science of IR out of its infancy", initiated the break between positive and normative research camps" (Booth and Erskine 2016, 290-291). The second came in the 1950/60s, which "urged the incorporation of scientific rigor in the social science" (Booth and Erskine 2016, 290-291). Recently, these aspects of IR practice have again begun to resurface through reflections, re-asking the question "what should we be doing as IR scholars?”.

This ultimately leaves us with three arguably standard questions that might see renewed interest in the periods to come, this time aimed at the topics debated in this article, such as what the objective of IR is; what the roles of values in the academic practice of IR are, and what the responsibility of IR practitioners is. As Ken Booth and Toni Erskine evaluated these challenges they leaned to several factors for consideration: A) professionalism or scientific IR; B) commitment to change; C) scientific inquiry as a tool; D) problem-solving approach; E) strategic vision; F) theoretical toleration; and G) empirical propositions with limited sets of values (Booth and Erskine 2016, 300). ${ }^{7}$ These considerations form the basis for reflectionists such as Jackson, Nye and Jentleson. As for another constitutional moments in IR, it is conceivable that further "bridging the gap" activity will lead to more discussion on academic ethics and convention.

7 Here we see a range of factors culminate to produce what Booth and Erskine state is "scientific activism”. This also leans on the works of Morton Kaplan $(1979 ; 2005)$ and Karl Deutsch (1968). 
Varying factors of synthesis, as well as blurred lines between traditional domains of IR methodology, remain subject to debate. Nonetheless, what is required is a significant effort to either alter the predominant norms of IR academia, or to reaffirm the traditional ones. This in no way supplements Popper-style demands of replacing the old with the new; instead it conforms further to Lakatos' "supplementary means". As the demands of policy practitioners intensify, it is likely that the increasing stresses of trans-domain research will steadily become noticeably professional. As Steven Walt points out, it is up to IR to re-discipline itself in this matter, whilst keeping in mind the general demands of conducting policy work (Walt 2005, 42). Finding a solution might, at least for a time, until IR develops further in line with the contemporary global environment that is always changing, appease certain contradictions of IR practitioners being associated with specific dichotomies, with their particular sets of goals and responsibilities. Seeking to erase such imbalances would be evidently futile, as something that is eagerly and increasingly practiced such as crossing the gap eventually becomes an accepted norm. However, by adjusting the essential works highlighted by the likes of Jackson will demonstrate not only IR's developing nature, but make it more applicable for a range of duties across the spectrum as well.

As for the risks, prudence is essential as the gap between science and politics is narrow. Understanding where, what, why, and how IR academicians conduct themselves, organize themselves and execute research is fundamental, and in many regards, requires a natural distance. Likewise, when bridging the gap, it must be kept in mind that, although a scholar may still be researching IR in general, each respective domain has differing goals and therefore diverging criteria. In no way, shape, or form, should scholars be deterred from bridging the gap; however, caution and remembering these aspects should be important considerations: "IR theorists can provide valuable ideas for policy makers without sacrificing our integrity and objectivity, but only if we decide we want to" (Walt 2005, 42). While retaining the caveat of caution, we should aim to further divulge an additional domain that possesses unique qualities that overreach the gap, essentially the recognition of a trans-domain. This may encompass a group of thinkers who can penetrate the three forms of theory/ puzzles and better facilitate a bridge. As interdisciplinary discourse and transdomainism are emerging, it is crucial for members of the IR knowledge system to facilitate further gradation. The organizational structure of the IR knowledge system could benefit from acknowledging a newly recognized trans-domain, hypothetically terming it policy thinkers. This would refer to those professionals who are able to cross the divide, retain and apply mutually exclusive practices without compromising themselves, and deliver them from the conundrums 
surrounding the IR knowledge system, IR practices and IR demands from all domains as well as all levels of theory. In a sense, they can embody the nature of pluralistic science.

\section{REFERENCES}

Abbot, Andrew. 2001. Chaos of Discipline. Chicago, IL: Chicago University Press.

Acharya, Amitav. 2014. The End of American World Order. Cambridge: Polity Press.

Anscombe, Gertrude Elizabeth Margaret. 1963. Intention. Cambridge, MA: Harvard University Press.

Bachelard, Gaston. 1938. The Formation of the Scientific Mind: A Contribution to a Psychoanalysis of Objective Knowledge. Gallimard: Paris.

Behnke, Andreas. 2001. "Grand Theory in the Age of Its Impossibility. Contemplations on Alexander Wendt." Cooperation and Conflict 36(1), 121-134.

Bliss, Henry Everlyn. 1929. The Organization of Knowledge and The System if the Science. New York, NY: Henry Holt and Company.

Booth, Ken and Toni Erskine. 2016. International Relations Theory Today, $2^{\text {nd }}$ Ed. [e-book]. New York, NY: Polity Press.

Bråten, Stein ed. 2006. Intersubjective communication and emotion in early ontogeny. Cambridge: Cambridge University Press.

Brown, Chris. 2013. "The Poverty of Grand Theory." European Journal of International Relations 19(3), 483-497.

Buzan, Barry and George Lawson. 2015. The Global Transformation: History, Modernity and the Making of International Relations. Cambridge: Cambridge University Press.

Buzan, Barry. 2018. "How and How Not to Develop IR Theory: Lessons from Core and Periphery." The Chinese Journal of International Politics 11(4), 391-414.

Codevilla, Angelo M. 2015. "The World According to Kissinger." Claremont Review of Books XV(2), 31-41.

Cox, Robert. 1981. "Social Forces, States and World Orders: Beyond International Relations Theory." Millennium 10(2), 126-155.

Delafield-Butt, Jonathan and Colwyn Trevarthen. 2013. "Theories of the 
development of human communication.” In Peter J. Schulz and Paul Cobley eds., Handbook of Communication Science. Berlin: De Gruyter, 199-221.

Desch, Michael. 2015. "Technique Trumps Relevance: The Professionalization of Political Science and the Marginalization of Security Studies." Perspectives on Politics 13(2), 377-393.

Deutsch, Karl. W. 1968. The Analysis of International Relations. Englewood Cliffs, NJ: Prentice-Hall.

Deutscher Bundestag. 2018. "Sigmar Gabriel." Accessed at https://www. bundestag.de/abgeordnete/biografien/G/gabriel_sigmar-519626 (26 July 2019).

Egeberg, Morten. 1994. "Bridging the Gap Between Theory and Practice: the Case of Administrative Policy." Governance: An International Journal of Policy and Administration 7(1), 83-98.

Eriksson, Johan. 2014. "On the Policy Relevance of Grand Theory." International Studies Perspectives 15, 94-108.

Feyerabend, Paul. 1978. Science in a Free Society. London: Verso Editions.

Foucault, Michel. 1970. The Order of Things: An Archaeology of the Human Sciences. New York, NY: Pantheon Books.

George, Alexander L. 1993. Bridging the Gap: Theory in Practice in Foreign Policy. Washington, DC: United States Institute for Peace Press.

Gilpin, Robert. 1981. War and Change in World Politics. Cambridge: Cambridge University Press.

Ginsburg, Mark B. and Jorge M. Gorostiaga. 2001. "Relationships between Researchers/Theorists and Policy Makers/Practitioners: Rethinking the Two-Cultures Thesis and the Possibility of Dialogue." Comparative Education Review 45(2), 173-196.

Grandin, Greg. 2015. Kissinger's Shadow. The Long Reach of America's Most Controversial Statesman. New York, NY: Picador.

Hellmann, Gunther, Friedrich Kratochwil, Yosef Lapid, Andrew Moravcsik, Iver B. Neumann, Steve Smith, Frank Harvey and Joel Cobb. 2003. "Are Dialogue and Synthesis Possible in International Relations?" International Studies Review 5(1), 123-153.

Hill, Christopher and Pamela Beshoff. 1994. The Two Worlds of International Relations: Academics, Practitioners and the trade in Ideas. London and New York, NY: Routledge.

Himmelrath, Armin. 2018. "Gabriel an der Uni Bonn. Vom Außenminister zum Vorleser [Gabriel at Bonn University. From Minister of Foreign Affairs to a Lecturer]." Spiegel (16 April). Accessed at https://www. 
spiegel.de/lebenundlernen/uni/universitaet-bonn-sigmar-gabrielhaelt-antrittsvorlesung-an-der-uni-a-1203176.html (23 July 2019).

Hollis, Martin and Steve Smith. 1990. Explaining and Understanding International Relations. Oxford: Clarendon Press.

Hopmann, P. Terrence, Dina A. Zinnes and David J. Singer. 1981. Cumulation in International Relations Research. Denver, CO: Graduate School of International Studies of the University of Denver.

Hurrell, Andrew. 2007. On Global Order. Power, Values, and the Constitution of International Society. New York, NY: Oxford University Press.

Hyndman, Jenifer. 2004. "Mind the gap: Bridging Feminist and Political Geography through Geopolitics." Political Geography 23(3), 307-322.

Ismar, Georg. 2018. "Gabriel doziert in Harvard [Gabriel teaches at Harvard]." Sächsische Zeitung (30 May). Accessed at https://www.saechsische.de/ gabriel-doziert-in-harvard--3945665.html (23 July 2019).

Jackson, Patrick Thaddeus. 2004. "Bridging the Gap: Towards a Realist Constructivist Dialogue." International Studies Review 6, 337-352. . 2010. "What Is Theory?" In Robert A. Denemark ed., The International Studies Encyclopedia. Oxford: Blackwell Publishing. . 2011. The Conduct of Inquiry in International Relations. Philosophy of Science and Its Implications for the Study of World Politics. London and New York, NY: Routledge. . 2017. "Consolations for the Scholar." International Studies Review 19, 699-703.

Jentleson, Bruce W. 2002. "The Need for Praxis: Bringing Policy Relevance Back In." International Security 26(4), 169-183.

Jentleson, Bruce W. and Ely Ratner. 2011. "Bridging the Beltway-Ivory Tower Gap.” International Studies Review 13(1), 6-11.

Kaplan, Morton A. 1979. Towards Professionalism in International Theory: Macrosystem Analysis. London: Collier Macmillan. . 2005 [1957]. System and Process in International Politics. Colchester: ECPR Press.

Katzenstein, Peter J. and RudraSil. 2010. "Beyond Paradigms: Analytic Eclecticism in the Study World of World Politics." Perspectives on Politics 8(2), 411-431.

Keohane, Robert O. 2018. "Political Science as a Vocation." In Kent Worchester ed., Navigating Political Science. Professional Advancement and Success in the Discipline. American Political Science Association: Washington, D.C, 249-256.

Keohane, Robert O. and Joseph S. Nye, Jr. 1977. Power and Interdependence: 
World Politics in Transition. Little Brown: Boston.

Kim, Hwajung. 2017. "Bridging the theoretical Gap between Public Diplomacy and Cultural Diplomacy." The Korean Journal of International Studies 15(2), 293-326.

Kissinger, Henry A. 1994. Diplomacy. New York, NY: Simon \& Schuster. . 2011. On China. New York, NY: Penguin Press. . 2014. World Order. New York, NY: Penguin Press.

Krüger, Uwe. 2013. Meinungsmacht. Der Einfluss von Eliten auf Leitmedien und AlphaJournalisten - eine kritische Netzwerkanalyse [Power of Opinion. The Influence of Elites on Media and Alpha Journalists - A Critical Network Analysis]. Cologne: Herbert von HalemVerlag.

Kupchan, Charles A. 2012. No One's World: The West, The Rising Rest, And The Coming Of Global Turn. Oxford: Oxford University Press.

Lakatos, Imre. 1976. Proofs and Refutations. The Logic of Mathematical Discovery. Cambridge: Cambridge University Press.

Lake, David A. 2011. "Why 'isms' Are Evil: Theory, Epistemology, Academic Sects as Impediments to Understanding and Progress.” International Studies Quarterly 55(2), 465-480. . 2013. "Theory Is Dead, Long Live Theory: The End of the Great Debates and the Rise of Eclecticism in International Relations." European Journal of International Relations 19(3), 567-587. . 2017. "Laws and Norms in the Making of International Hierarchies." In Ayşe Zarakol ed., Hierarchies in World Politics. Cambridge: Cambridge University Press, 17-42.

Lantis, Jeffrey S. 2009. "Strategic culture and Tailored Deterrence: Bridging the Gap Between theory and Practice." Contemporary Security Policy 30(3), 467-485.

Lepgold, Joseph, and MiroslavNincic. 2002. Beyond the Ivory Tower. New York, NY: Columbia University Press.

Lepgold, Joseph. 1998. "Is Anyone Listening? International Relations Theory and the Problem of Policy Relevance." Political ScienceQuarterly 113(1), 43-62.

Linklater, Andrew. 2009. "Grand Narratives and International Relations." Global Change, Peace \& Security 21(1), 3-17.

Marková, Ivana, 2003. "Constitution of the Self: Intersubjectivity and Dialogicality." Culture \& Psychology, 9(3), 249-259.

Mead, Lawrence M. 1985. "Science Versus Analysis: A False Dichotomy." Journal of Policy Analysis and Management 4(3), 419-422.

Mingst, Karen A. and Ivan M. Arreguin-Toft. 2011. Essentials of International 
Relations. New York, NY: W.W. Norton \& Company.

Morgenthau, Hans J. 1958. Dilemmas of Politics. Chicago, IL: Chicago University Press.

Nagy, Emese. 2008. Innate intersubjectivity: Newborns' sensitivity to communication disturbance. Developmental Psychology, 44(6), 17791784 .

Nincic, Miroslav and Joseph Lepgold. 2000. Being Useful: Policy Relevance and International Relations Theory. Ann Arbor: University of Michigan Press.

Nye Jr., Joseph S. 1990. Bound to Lead: The Changing Nature of American Power. New York, NY: Basic Books.

. 2004. Soft Power. The Means to Success in World Politics. New York, NY: Public Affairs.

. 2008. "Bridging the Gap between Theory and Policy." Political Psychology 29(4), 593-603.

Onuf, Nicholas Greenwood. 1989. World of Our Making: Rules and Rule in social Theory and International Relations. Columbia: University of South Carolina Press.

Peterson, Susan, Michael J. Tierney and Daniel Maliniak. 2005. "Inside the Ivory Tower." Foreign Policy 151: 58-64.

Popper, Karl. 2002. The Logic of Scientific Discovery. London: Routledge.

Rathburn, Brian. 2012. "Politics and Paradigm Preferences: The Implicit Ideology of International Relations Scholars.” International Studies Quarterly 56(3), 607-622.

Riley, Philip. 2007. Language, culture, and Identity, London: Continuum.

Shipan, Charles R. and Craig Volden 2012. "Policy Diffusion: Seven Lessons for Scholars and Practitioners." Public Administration Review 72(6), 788-796.

Spiel, Christiane and Dagmar Strohmeier. 2012. "Evidence-Based Practice and Policy: When Researchers, Policy Makers, and Practitioners Learn How to Work Together." European Journal of Developmental Psychology 9(1), 150-162.

Strange, Susan. 1996. The Retreat of the State: The Diffusion of Power in the World Economy. Cambridge: Cambridge University Press.

Stürmer, Michael. 1987. "Geschichte in einem geschichtslosen Land [History in a Land without History]." In Eugen R. Piper ed., Historikerstreit. Die Dokumentation der Kontroverse um die Einzigartigkeit der nationalsozialisischen Judenvernichtung [Historians' Dispute. The Documentation of the Controversy on the Exceptionality of the 
Persecution of Jews under the National Socialists]. Munich and Zurich: Piper, 36-38.

Suri, Jeremi. 2008. "Henry Kissinger, the American Dream, and the Jewish Immigrant Experience in the Cold War." Diplomatic History 32(5), 719-747.

Tanter, Raymond and Richard Henry Ullman. 1972. Theory and Policy in International Relations. Princeton, NJ: Princeton University Press.

Thomson, Janice E. 1995. "State Sovereignty in International Relations:

Bridging the Gap Between Theory and Empirical Research." International Studies Quarterly 39(2), 213-233.

Trevarthen, Colwyn. 2008. "Why theories will differ." In Jordan Zlatev, Timothy P. Racine, Chris Sinha and Esa Itkonen eds., The Shared Mind: Perspectives on Intersubjectivity. Amsterdam: John Benjamins Publishing, vii-xiii.

Trow, Martin. 1984. "Researchers, Policy Analysts and Policy Intellectuals." In

Thorsten Husen and Maurice Kogan eds., Educational Research and Policy: How Do They Relate?. Pergamon: Oxford, 261-282.

Walt, Stephen M. 1998. "International Relations: One World, Many Theories." Foreign Policy 110, 29-46.

. 2005. "The Relationship between Theory and Policy in International Relations." Annual Review of Political Science 8(1), 23-46.

Weber, Max. 1994. Wissenschaft Als Beruf - Politik Als Beruf, Edited by W.J. Mommsen and W. Schluchter. Tübingen: J. C. B. Mohr.

Weiss, Carol H. 1978. "Improving the Linkage Between Social Research and Public Policy." In Laurence E. Lynn ed., Knowledge and Policy: The Uncertain Connection. Washington, DC: National Academy of Sciences Press, 23-81.

Wendt, Alexander. 1991. "Bridging the Theory/Meta-theory Gap in International Relations." Review of International Studies 17(4), 383392.

Wilson, James Q. 1981. "Policy Intellectuals and Public Policy." The Public Interest 64.

Zakaria, Fareed. 2009. The Post-American World: And The Rise Of The Rest. London: Penguin Books. 